\title{
Interest of anatomical segmentectomy over lobectomy for lung cancer: a nationwide study
}

\author{
Elodie Berg ${ }^{1}$, Leslie Madelaine ${ }^{1}$, Jean-Marc Baste ${ }^{2}$, Marcel Dahan $^{3}$, Pascal Thomas ${ }^{4}$, \\ Pierre-Emmanuel Falcoz ${ }^{5}$, Emmanuel Martinod ${ }^{6}$, Alain Bernard ${ }^{1}$, Pierre-Benoit Pagès ${ }^{1}$
}

${ }^{1} \mathrm{CHU}$ Dijon Bourgogne, Hôpital François Mitterrand, Dijon, France; ${ }^{2} \mathrm{CHU}$ Rouen, Hôpital Charles-Nicolle, Rouen, France; ${ }^{3} \mathrm{CHU}$ Toulouse, Hôpital Larrey, Toulouse, France; ${ }^{4} \mathrm{CHU}$ Marseille, Hôpital Nord, Marseille, France; ${ }^{5} \mathrm{CHU}$ Strasbourg, Hôpital Civil, Strasbourg, France; ${ }^{6} \mathrm{APHP}$, Hôpital Avicenne, Bobigny, France

Contributions: (I) Conception and design: PB Pagès, A Bernard, E Berg; (II) Administrative support: P Thomas, PE Falcoz, E Martinod; (III) Provision of study materials or patients: E Berg, L Madelaine, JM Baste; (IV) Collection and assembly of data: E Berg, L Madelaine, JM Baste; (V) Data analysis and interpretation: E Berg, A Bernard, PB Pagès, L Madelaine; (VI) Manuscript writing: All authors; (VII) Final approval of manuscript: All authors.

Correspondence to: Pierre-Benoit Pagès, MD, PhD. Department of Thoracic Surgery, CHU Dijon Bourgogne, Hôpital Francois Mitterrand, 14 rue Gaffarel, BP 7790821079 Dijon, France. Email: pierrebenoit.pages@chu-dijon.fr.

Background: Anatomical segmentectomy is an alternative to lobectomy for early-stage lung cancer (LC) or in patients at high risk. The main objective of this study was to compare the morbidity and mortality associated with these two types of pulmonary resection using data from the French National Epithor database. Methods: All patients who underwent lobectomy or segmentectomy for early-stage LC from January $1^{\text {st }}$ 2014 to December $31^{\text {st }} 2016$ were identified in the Epithor database. The primary endpoint was morbidity; the secondary endpoint was postoperative mortality. Propensity score matching was implemented and used to balance groups. The results were reported as odds ratios (OR) and 95\% confidence intervals (CI).

Results: During the study period, 1,604 segmentectomies (9.78\%) and 14,786 lobectomies (90.22\%) were performed. After matching, the segmentectomy group experienced significantly less atelectasis (OR 0.54; 95\% CI: 0.4-0.75, P<0.0001), pneumonia (OR 0.72; 95\% CI: 0.55-0.95, P=0.02), prolonged air leaks (OR 0.75; 95\% CI: 0.64-0.89, $\mathrm{P}=0.001$ ) or bronchopleural fistula (OR 0.35; 95\% CI: 0.14-0.83, P=0.017), and fewer patients had at least one complication (OR 0.7; 95\% CI: $0.62-0.78, \mathrm{P}<0.0001$ ). According to the Clavien-Dindo classification, postoperative complications were significantly less severe in the segmentectomy group (OR 0.52; 95\% CI: 0.37-0.74, $\mathrm{P}<0.0001$ ). There was no significant difference in postoperative mortality at 30 days (OR 0.67; 95\% CI: 0.38-1.20, $\mathrm{P}=0.18$ ), 60 days (OR 0.78; 95\% CI: 0.42-1.47, $\mathrm{P}=0.4$ ), or 90 days (OR 0.77; 95\% CI: 0.45-1.34, P=0.36).

Conclusions: Anatomical segmentectomy is an alternative surgical approach that could reduce postoperative morbidity, but it does not appear to affect mortality.

Keywords: Segmentectomy; lobectomy; postoperative complications; mortality; early-stage lung cancer (early-stage LC)

Submitted Jun 13, 2020. Accepted for publication Mar 25, 2021.

doi: $10.21037 /$ jtd-20-2203

View this article at: http://dx.doi.org/10.21037/jtd-20-2203

\section{Introduction}

Lung cancer (LC) remains the leading cause of mortality worldwide, and was responsible for 1,761,007 deaths in Europe in 2018 (1). In patients with localized LC, surgical management remains the best curative treatment as indicated by the 2013 American College of Chest Physicians (ACCP) guidelines, which recommend lobar resection (2). In these guidelines, segmentectomy was described as an alternative to lobectomy in "compromised" patients if 
margins greater than $2 \mathrm{~cm}$ could be achieved (2).

These guidelines are partly based on the results of the Lung Cancer Study Group which led a prospective, multiinstitutional randomized trial comparing lobectomy to sublobar resection in 1995 (3). This trial showed that lobectomy was superior to sublobar resection. Therefore, and despite the limits of this trial including wedge resection, lobectomy was accepted as the standard resection for early LC. Since then, numerous papers comparing lobectomy and segmentectomy have been published regarding overall survival, but this topic remains controversial.

In recent years, the practice of segmentectomy has expanded. Several reasons could explain this trend: firstly, the increased incidence of early stage LC managed by surgery, secondly, the ageing of patients with localized LC, and, thirdly, the development of multimodal surgical navigation systems and minimally invasive surgery (4-9).

In 2019, the results of the first randomized control trial comparing anatomical pulmonary segmentectomy to lobectomy was published from data recorded in highly specialized Japanese centers (10). It did not highlight any differences in postoperative mortality, but revealed that, compared to lobectomy, segmentectomy was a predictor of severe pulmonary complications including air leaks and empyema (10). Data regarding overall survival were not yet available.

The main objective of our study was to compare morbidity for the two types of pulmonary resection using data from the Epithor National database. The secondary endpoint was postoperative mortality at 30,60 or 90 days. The Epithor database collects data from more than 100 hospitals and is thus more representative of real-life thoracic surgery practices than databases that collect data from highly specialized centres alone. A Kernel matching analysis was used to yield a more powerful and comprehensive comparison of postoperative complications and mortality.

We present the following article in accordance with the STROBE reporting checklist (available at http://dx.doi. org/10.21037/jtd-20-2203).

\section{Methods}

\section{Data collection}

Epithor is a government-recognized clinical database that is financed by the French National Cancer Institute (Institute National du Cancer) for data-quality monitoring. Epithor has been accredited as a methodologically appropriate tool for assessing professional surgical practices by the French Health Authorities (Haute Autorité de Santê), a governmental agency dedicated to improving the quality of patient care and to guaranteeing equality within the health care system. French hospitals are now required to participate in Epithor in order to obtain their medical accreditation and thoracic surgery unit certification $(11,12)$. Data accuracy has been checked in regular external on-site audits since 2010 (11).

\section{Study population}

The study was conducted in accordance with the Declaration of Helsinki (as revised in 2013). From January $1^{\text {st }}, 2014$ to December $31^{\text {st }}, 2016,16,390$ patients underwent segmentectomy or lobectomy for LC in France. Baseline demographic and clinical characteristics include age, gender, medical history (chronic bronchitis, tobacco use, chronic heart failure, alcoholism, neurological disease, haematological disease, cancer history, thoracotomy history, chronic respiratory failure), American Society of Anaesthesiologist (ASA) score, World Health Organization (WHO) performance status, body mass index (BMI), and forced expiratory volume (FEV1). The surgical technique was the video assisted thoracic surgery (VATS) or thoracotomy. For all patients, LC was diagnosed with pathology analyses according to the 2004 World Health Organization classification of LC (13).

\section{Outcome measurements}

The primary endpoint was postoperative complications, including atelectasis, prolonged air leaks (>5 days), bronchopleural fistula, pneumonia, haemorrhage, empyema or at least one complication (14). The Clavien-Dindo classification was used in order to assess the severity of the postoperative complications (14).

The secondary endpoints were postoperative mortality at 30,60 and 90 days, defined as any patient who died within the first 90 days following surgery, or the initial hospitalization if longer.

\section{Missing data}

The proportion of missing information regarding tumour stage, lymph node involvement and quality of resection for this study were respectively $18 \%, 20.5 \%$ and $20 \%$. We applied a multiple imputation framework to compensate for 
missing FEV data. For the variable TNM stage, we created a variable category to include in the analysis. We assumed that the missing data were missing at random.

\section{Statistical analysis}

We used kernel matching algorithms that were developed from a nonparametric regression method for curve smoothing $(15,16)$. A mirrored histogram was used to measure the discriminatory ability of the Kernel matching. Kernel matching used a search algorithm to find a set of weights for each covariate so that the version of optimal balance is achieved after matching (16). We evaluated the ability of Kernel matching to balance the measured covariates between segmentectomy and lobectomy by reducing the standardized difference (17). The standardized difference is the difference between sample means in the segmentectomy and lobectomy group divided by the standard deviation in the treatment group overall (18).

Finally, odds ratios (OR) were used for dichotomous variables: postoperative mortality and postoperative complications. For this study, we used Stata, version 14 (StataCorp, college station, TX, USA).

\section{Results}

\section{Study cohort}

Over the study period, 1,604 segmentectomies and 14,786 lobectomies were performed and recorded in the Epithor database.

Unmatched patient demographics, surgical management, tumour and hospital characteristics are presented in Table 1. In the segmentectomy group, the proportion of women and older patients was significantly higher. They were more likely to have a history of pulmonary disease, heart disease, cancer, or previous thoracotomy, and there was a higher proportion of ASA score $\geq 3$, performance status score $\geq 2$, BMI $\geq 28 \mathrm{~kg} / \mathrm{m}^{2}$ and lower FEV1 (Table 1). Segmentectomies were more often performed by VATS in higher volume non-teaching hospitals. The diagnoses was more often for stage I, without lymph node involvement, but segmentectomies resulted in more incomplete $\mathrm{R} 1$ or $\mathrm{R} 2$ resection (Table 1).

The characteristics of the matched groups are outlined in Table 2. In the matched samples, 1,594 patients in the segmentectomy group were balanced with 14,477 patients in the lobectomy group. None of the patient characteristics were significantly different for the 2 groups (Table 2).

\section{Kernel matching estimation}

The mirrored histogram shows a well-balanced distribution of covariates after kernel matching (Figure 1). The median distribution of the standardized biases was of 0.045 for the kernel matching approach (Table 2). The standardized difference never reached the value of $10 \%$ (Table 2), indicating that the covariates were well balanced for the 2 groups.

\section{Postoperative complications}

After matching, we found that the segmentectomy group had significantly less atelectasis (OR 0.54; 95\% CI: 0.4-0.75, $\mathrm{P}<0.0001$ ), pneumonia (OR 0.72 , 95\% CI: $0.55-0.95$, $\mathrm{P}=0.02$ ), prolonged air leaks (OR 0.75, 95\% CI: 0.64-0.89, $\mathrm{P}=0.001$ ), bronchopleural fistula (OR $0.35,95 \% \mathrm{CI}$ : $0.14-0.83), \mathrm{p}=0.17$ ) or at least one complication (OR 0.7, 95\% CI: $0.62-0.78, \mathrm{P}<0.0001)$. According to the ClavienDindo classification, the postoperative complications were significantly less severe in the segmentectomy group (OR 0.52, 95\% CI: $0.37-0.74, \mathrm{P}<0.0001$ ) (Table 3).

\section{Postoperative mortality}

There were no significant differences in postoperative mortality at 30 days (OR 0.67 ; $95 \%$ CI: $0.38-1.2, \mathrm{P}=0.18$ ), 60 days (OR $0.78 ; 95 \%$ CI: $0.42-1.47, \mathrm{P}=0.4$ ), or 90 days (OR 0.77; 95\% CI: 0.45-1.34, $\mathrm{P}=0.36$ ).

\section{Discussion}

Almost 50 years ago, Jensik et al. was the first to suggest that segmentectomy could be equivalent to lobectomy in terms of overall survival and recurrence for early LC (19). However, in 1995, data from the LC Study Group indicated that lobectomy should be the standard procedure for early primary LC (3). Since then, considerable amounts of data have been published, including from large databases, yet no large randomized controlled trials (excluding wedge resection) have definitely settled the interest of segmentectomy over lobectomy for early primary LC, especially regarding overall survival and recurrence (20-25). 
Table 1 Unmatched patient baseline characteristics

\begin{tabular}{|c|c|c|c|}
\hline Patient characteristics & Segmentectomy $(n=1,604)$ & Lobectomy $(n=14,786)$ & $\mathrm{P}$ Value \\
\hline \multicolumn{4}{|l|}{ Gender } \\
\hline Male & $972(61 \%)$ & $9,595(65 \%)$ & 0.001 \\
\hline Female & $632(39 \%)$ & $5,191(35 \%)$ & \\
\hline Age (Years) & $66 \pm 9$ & $64 \pm 10$ & 0.00001 \\
\hline Chronic bronchitis & $466(29 \%)$ & $3,139(21 \%)$ & 0.0001 \\
\hline Smoker & $365(23 \%)$ & $3,760(25 \%)$ & 0.02 \\
\hline Chronic heart failure & $45(3 \%)$ & $301(2 \%)$ & 0.04 \\
\hline Alcoholism & $99(6 \%)$ & $740(5 \%)$ & 0.04 \\
\hline Hematological disease & $42(2.6 \%)$ & $255(1.7 \%)$ & 0.01 \\
\hline Cancer history & $613(38 \%)$ & $4,225(28 \%)$ & 0.0001 \\
\hline Thoracotomy history & 244 (15\%) & $988(6.7 \%)$ & 0.0001 \\
\hline Chronic respiratory failure & $142(9 \%)$ & $856(5.8 \%)$ & 0.0001 \\
\hline \multicolumn{4}{|l|}{ ASA score } \\
\hline 1 & $308(19 \%)$ & $2,370(16 \%)$ & 0.0001 \\
\hline 2 & 739 (46\%) & $7,699(52 \%)$ & \\
\hline$\geq 3$ & $557(35 \%)$ & $4717(32 \%)$ & \\
\hline$<24 \mathrm{Kg} / \mathrm{m}^{2}$ & $695(43 \%)$ & $6,634(45 \%)$ & 0.16 \\
\hline 24 to $28 \mathrm{Kg} / \mathrm{m}^{2}$ & 435 (27\%) & $4,114(28 \%)$ & \\
\hline$>28 \mathrm{Kg} / \mathrm{m}^{2}$ & $474(30 \%)$ & $4,038(27 \%)$ & \\
\hline Forced expiratory volume (\%) & $82 \pm 20$ & $85 \pm 20$ & 0.00001 \\
\hline \multicolumn{4}{|l|}{ Surgical Management } \\
\hline VATS & $942(59 \%)$ & $6,121(41 \%)$ & 0.0001 \\
\hline \multicolumn{4}{|l|}{ Hospital characteristics } \\
\hline Hospital volume & $226 \pm 236$ & $208 \pm 197$ & 0.0005 \\
\hline \multicolumn{4}{|l|}{ Type } \\
\hline Non-teaching hospital & $171(11 \%)$ & $1,325(9 \%)$ & 0.04 \\
\hline Private hospital & $551(34 \%)$ & $5,006(34 \%)$ & \\
\hline Teaching hospital & $876(55 \%)$ & $8,441(57 \%)$ & \\
\hline
\end{tabular}

Table 1 (continued) 
Table 1 (continued)

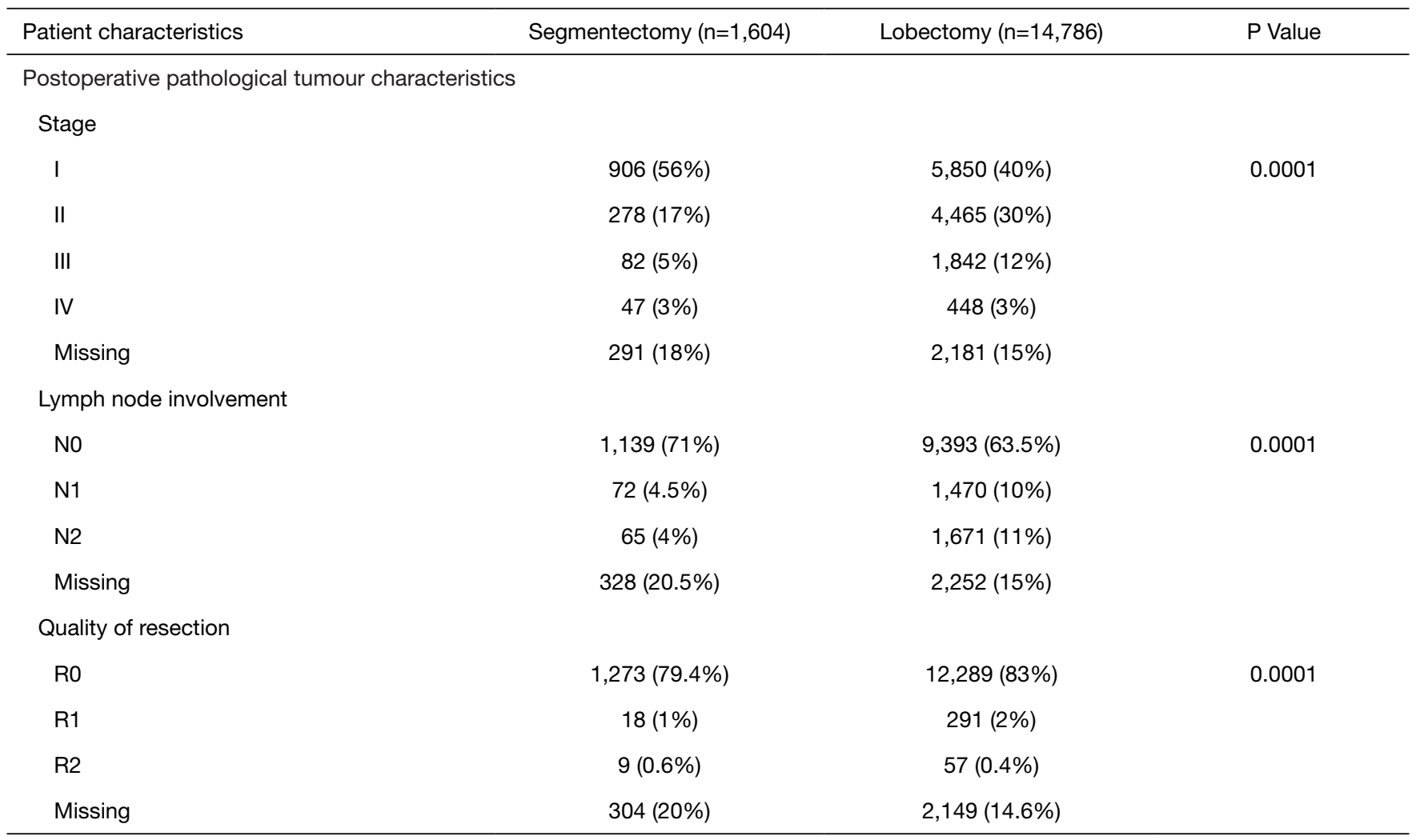

Table 2 Patients' baseline characteristics after kernel matching with their standardized difference

\begin{tabular}{|c|c|c|c|c|}
\hline Patient characteristics & Segmentectomy $(n=1,594)$ & Lobectomy $(n=14,477)$ & $P$ value & Standardized difference \\
\hline Female & $39 \%$ & $39 \%$ & 0.9 & 0.002 \\
\hline Age (minus mean) (years) & 1.11 & 1.08 & 0.9 & 0.003 \\
\hline \multicolumn{5}{|l|}{ Medical history } \\
\hline Smoker & $23 \%$ & $23 \%$ & 0.9 & 0.002 \\
\hline Chronic Heart failure & $3 \%$ & $2 \%$ & 0.9 & 0.003 \\
\hline Alcoholism & $6 \%$ & $6 \%$ & 0.9 & 0.003 \\
\hline Neurological disease & $1 \%$ & $1 \%$ & 0.9 & -0.005 \\
\hline Thoracotomy history & $15 \%$ & $15 \%$ & 0.7 & 0.015 \\
\hline Chronic respiratory failure & $9 \%$ & $9 \%$ & 0.9 & 0 \\
\hline
\end{tabular}

Table 2 (continued) 
Table 2 (continued)

\begin{tabular}{|c|c|c|c|c|}
\hline Patient characteristics & Segmentectomy $(n=1,594)$ & Lobectomy ( $n=14,477)$ & $P$ value & Standardized difference \\
\hline 2 & $46 \%$ & $47 \%$ & 0.7 & -0.012 \\
\hline$\geq 3$ & $35 \%$ & $34 \%$ & 0.9 & 0.006 \\
\hline \multicolumn{5}{|l|}{ Performance status } \\
\hline$\geq 2$ & $166(10.5 \%)$ & $1247(8 \%)$ & 0.9 & 0.002 \\
\hline \multicolumn{5}{|l|}{ Body mass index } \\
\hline 24 to $28 \mathrm{Kg} / \mathrm{m}^{2}$ & $27 \%$ & $27 \%$ & 0.9 & 0.004 \\
\hline$>28 \mathrm{~kg} / \mathrm{m}^{2}$ & $29 \%$ & $29 \%$ & 0.9 & 0 \\
\hline VATS & $58.5 \%$ & $59 \%$ & 0.6 & -0.017 \\
\hline \multicolumn{5}{|l|}{ Hospital characteristics } \\
\hline Hospital volume (minus mean) & 16 & 14.7 & 0.8 & 0.008 \\
\hline \multicolumn{5}{|l|}{ Type } \\
\hline Teaching hospital & $55 \%$ & $55 \%$ & 0.9 & -0.003 \\
\hline \multicolumn{5}{|c|}{ Postoperative pathological tumour characteristics } \\
\hline \multicolumn{5}{|l|}{ Stage } \\
\hline II & $17 \%$ & $17 \%$ & 0.7 & 0.012 \\
\hline N2 & $4 \%$ & $4 \%$ & 0.8 & 0.006 \\
\hline Missing & $20 \%$ & $20 \%$ & 0.9 & -0.002 \\
\hline \multicolumn{5}{|l|}{ Quality of resection } \\
\hline $\mathrm{R} 1$ & $1 \%$ & $1 \%$ & 0.8 & 0.005 \\
\hline $\mathrm{R} 2$ & $0.5 \%$ & $0.5 \%$ & 0.9 & 0.004 \\
\hline Missing & $19 \%$ & $19.6 \%$ & 0.7 & -0.013 \\
\hline
\end{tabular}

A standardized difference greater than $0.1(10 \%)$ represents meaningful imbalance in a given variable between treatment groups.

\$, polynomial transformation: $\mathrm{X}=\mathrm{FEV} / 100 \cdot \mathrm{X}^{-0.5}-1.08$

Nowadays, the ACCP recommends segmentectomy over lobectomy in patients with a major risk of perioperative mortality or competing causes of death such as age or other co-morbidities (2). However, the outcomes of segmentectomy and lobectomy have rarely been compared. In their recent randomized controlled trial, Suzuki et al. (10) reported finding no difference in postoperative outcomes between the two approaches. 


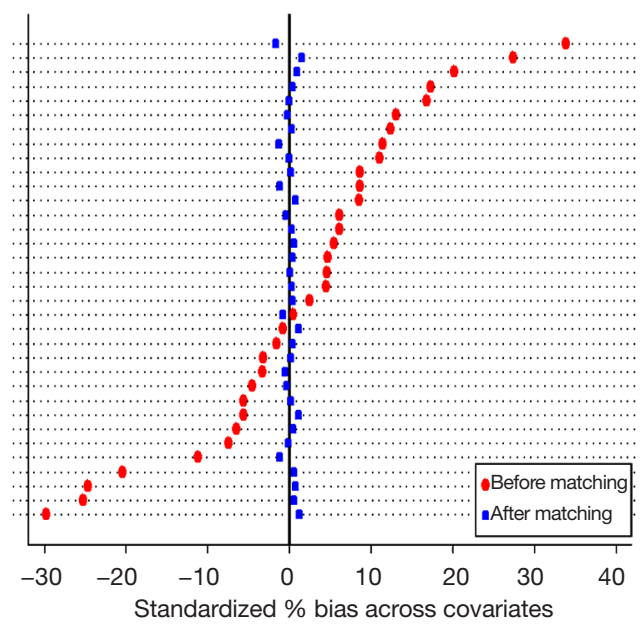

Figure 1 Standardized differences of covariates before and after matching.

\section{Postoperative mortality}

After matching, our analysis found no difference in mortality rates between the two types of pulmonary resection, even after 90 days. Other single centre studies have highlighted comparable results: there was no decrease in postoperative mortality even though it could have been expected after a more limited resection (26-28). Only Zhang et al., who reported data from ten different centres including 106 segmentectomies with 1,164 lobectomies, showed a trend towards decreased postoperative mortality after segmentectomy compared with lobectomy $(0.9 \%$ vs. $5 \%, \mathrm{P}=0.0894)$. As mentioned above, Suzuki et al. found similar postoperative mortality after comparing 552 segmentectomies with 554 lobectomies. Their randomized trial was conducted in almost 10 centres with surgeons highly-skilled in the practice of complex segmentectomy, which could explain the lack of difference. Furthermore, the ongoing increase in quality of care has led to a dramatic decrease in postoperative mortality after lobectomy. In recent studies, hospital mortality after lung resection ranges from $0.9 \%$ to $2.3 \%$ in clinical databases and from $1.8 \%$ to $3 \%$ in administrative databases (29-31). The progressive improvement in quality of care has likely reduced the difference in outcomes between segmentectomy and lobectomy.

\section{Postoperative complications}

Though postoperative mortality was similar in the two groups, postoperative complications appeared to be significantly more frequent in the lobectomy group. We found that patients were more likely to have at least one complication after lobectomy, with an OR of 0.7 in favour of segmentectomy. Deng et al., reporting data from the Mayo Clinic, showed that after matching of 177 segmentectomies to 531 lobectomies operated by open thoracotomy, there were fewer complications in the segmentectomy group ( $32.2 \%$ vs. $41.6 \%, \mathrm{P}=0.02)$. However, this difference disappeared when they used a matching analysis to compare patients who were operated with a VATS approach (28).

Ohtsuka et al., whose study compared 61 segmentectomies to 61 lobectomies after propensity score matching, highlighted a higher rate of postoperative complications after segmentectomy, mostly due to pulmonary air leaks (32). Air leaks may occur more often after segmentectomy because a longer section of pulmonary parenchyma is stapled or because the intersegmental plane is divided using electrocautery and then covered with a fibrin sealant. Others studies have reported similar rates of air leaks in both segmentectomy and lobectomy $(26,27,33)$. Our study showed comparatively fewer pulmonary air leaks after segmentectomy. In our opinion, because the remaining segment is placed against the remaining lobes after segmentectomy, the duration of air leaks should be shorter.

Moreover, we found fewer postoperative pulmonary complications after segmentectomy, whether it was atelectasis or pneumonia. These complications are rarely mentioned in the literature, and the mechanisms are uncertain. Suzuki et al. highlighted more pulmonary air leaks or fistula after segmentectomy $(6.5 \%$ vs. $3.8 \%)$, but they did not distinguish between pulmonary air leaks and bronchial fistula. Two additional studies found similar levels or less pneumonia after lobectomy. These varying results are difficult to explain. Our study includes a large number of lobectomies for which we were not able to specify the location of the resected lobe. So, as previously described, patients who undergo lobectomy have a higher risk of developing air leaks, especially after upper lobectomy (34). Regarding atelectasis or pneumonia, we did not find any explanation in the literature. We believe that these differences may be linked to the fact that segmentectomy preserves more lung function than lobectomy, resulting in earlier rehabilitation and a decrease in postoperative pulmonary complications; the differences may also be associated with the quality of patient outcomes data entered in the database (35). 
Table 3 Comparison of outcome variables in segmentectomy vs. lobectomy in kernel matched sample

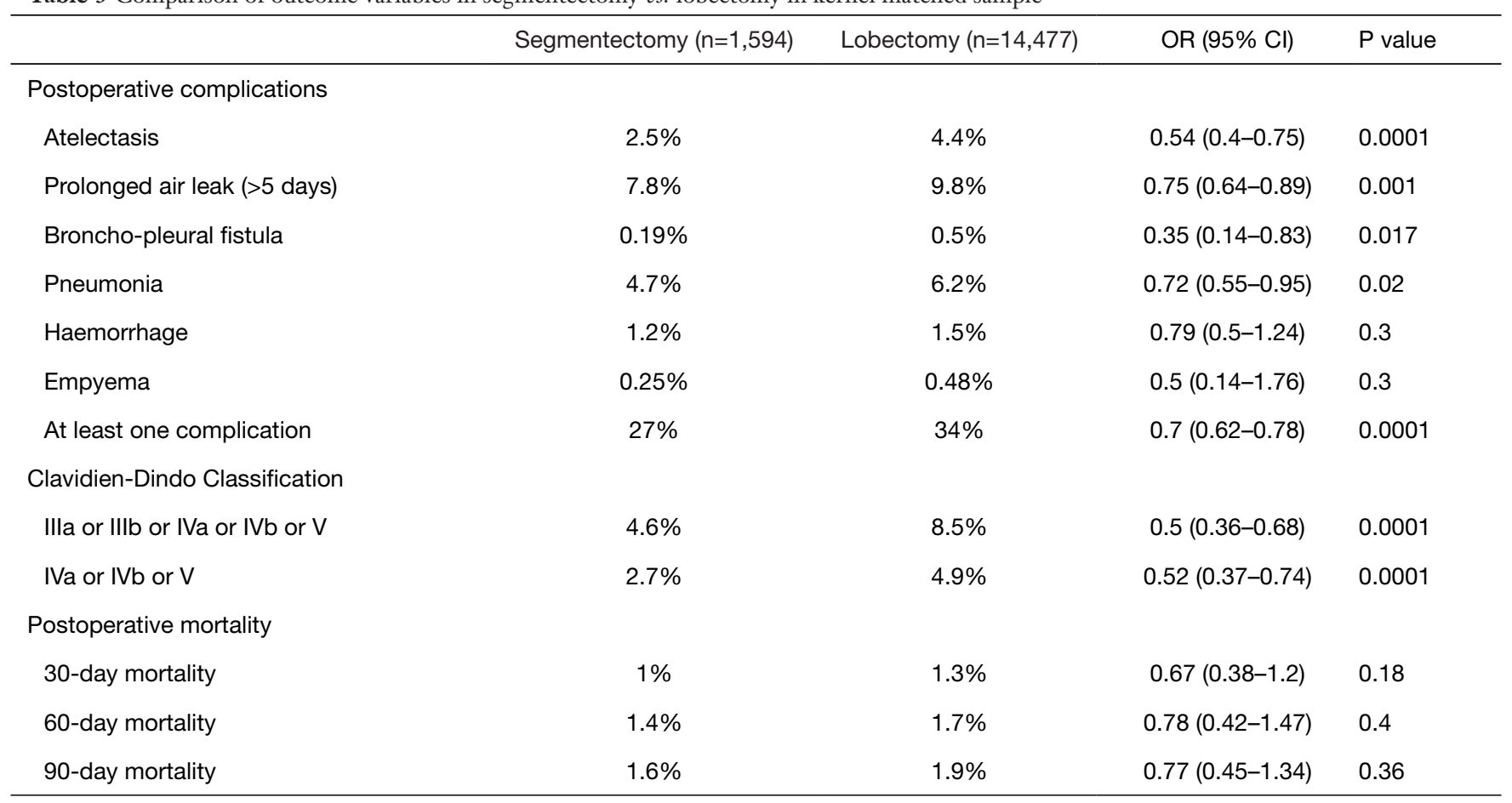

\section{Severity of postoperative complications}

We found that segmentectomy halved the risk of developing a severe postoperative complication (higher than grade IIIa in the Clavien-Dindo classification, meaning that the patient needs additional surgical management under local anaesthesia or more) (14). In their trial, Suzuki et al. used the Common Terminology Criteria for Adverse Events (CTCAE) to define their complications (10). They found no difference in the occurrence of complications needing additional surgical management or a prolonged hospital stay when they compared the two types of pulmonary resection. Handa et al. showed that patients were more likely to develop a grade IIIa complication or higher after lobectomy than after segmentectomy $(9.6 \%$ vs. $3 \%, \mathrm{P}=0.076)$, but the results did not reach significance, probably due to the study's small sample size (26).

\section{Strengths and limitations}

The main strengths of this study are the use of a national database, which provided a large number of patients and a homogeneous population. In addition, the large number of patients in both groups allowed us to make powerful comparisons. The homogeneous population reduced the sample size needed for the matching comparison, and the reasonable length of the study period decreased historical bias.

However, any study involving a large database raises the question of the quality and exhaustiveness of the prospectively entered data such as comorbidities, and observational studies are notoriously full of missing values. Few details were available about the surgical technique, especially concerning the location of the resected segment, the type of the segmentectomy (simplex or complex), the value of the preoperative of diffusing capacity of the lung for carbon monoxide (DLCO), the value of the cardiopulmonary exercise testing, or postoperative predicted FEV1 value. We used Kernel matching to create comparable cohorts; however, we cannot be certain that the Kernel matching perfectly neutralized all of the confounding variables.

\section{Conclusions}

Anatomical segmentectomy is a surgical alternative that could reduce the occurrence and severity of postoperative complications. However, segmentectomy was not found to impact postoperative mortality at 30 days, 60 days or 90 days. 


\section{Acknowledgments}

This work was performed on behalf of the French Society of Thoracic and Cardiovascular surgery (Société Française de Chirurgie Thoracique et CardioVasculaire - SFCTCV). We are grateful to all the French thoracic surgeons who participated in this study and have been listed in Appendix 1. The authors would like to thank Suzanne Rankin (Dijon University Hospital) for reviewing the manuscript.

Funding: None.

\section{Footnote}

Reporting Checklist: The authors have completed the STROBE reporting checklist. Available at http://dx.doi. org/10.21037/jtd-20-2203

Conflicts of Interest: All authors have completed the ICMJE uniform disclosure form (available at http://dx.doi. org/10.21037/jtd-20-2203). JMB reports personal fees from INTUITIVE SURGICAL, outside the submitted work. PBP reports personal fees from INTUITIVE SURGICAL, personal fees from MEDTRONIC, outside the submitted work. The other authors have no conflicts of interest to declare.

Ethical Statement: The authors are accountable for all aspects of the work in ensuring that questions related to the accuracy or integrity of any part of the work are appropriately investigated and resolved. The study was conducted in accordance with the Declaration of Helsinki (as revised in 2013). Institutional ethical approval and Individual informed consent were waived.

Open Access Statement: This is an Open Access article distributed in accordance with the Creative Commons Attribution-NonCommercial-NoDerivs 4.0 International License (CC BY-NC-ND 4.0), which permits the noncommercial replication and distribution of the article with the strict proviso that no changes or edits are made and the original work is properly cited (including links to both the formal publication through the relevant DOI and the license). See: https://creativecommons.org/licenses/by-nc-nd/4.0/.

\section{References}

1. International agency for research on cancer. Globocan 2018: Lyon, France. Available online: https://gco.iarc.fr/
today/data/factsheets/cancers/15-Lung-fact-sheet.pdf

2. Howington JA, Blum MG, Chang AC, et al. Treatment of stage I and II non-small cell lung cancer: Diagnosis and management of lung cancer, 3rd ed: American College of Chest Physicians evidence-based clinical practice guidelines. Chest 2013;143:e278S-313S.

3. Ginsberg RJ, Rubinstein LV. Randomized trial of lobectomy versus limited resection for T1 N0 non-small cell lung cancer. Lung Cancer Study Group. Ann Thorac Surg 1995;60:615-22; discussion 622-3.

4. Morgant MC, Pagès PB, Orsini B, et al. Time trends in surgery for lung cancer in France from 2005 to 2012: a nationwide study. Eur Respir J 2015;46:1131-9.

5. National Lung Screening Trial Research Team, Aberle DR, Adams AM, et al. Reduced lung-cancer mortality with low-dose computed tomographic screening. N Engl J Med 2011;365:395-409.

6. Pagès PB, Mariet AS, Madelaine L, et al. Impact of videoassisted thoracic surgery approach on postoperative mortality after lobectomy in octogenarians. J Thorac Cardiovasc Surg 2019;157:1660-7.

7. Pagès PB, Mariet AS, Pforr A, et al. Does age over 80 years have to be a contraindication for lung cancer surgery-a nationwide database study. J Thorac Dis 2018;10:4764-73.

8. Lachkar S, Baste JM, Salaün M, et al. All things are created twice, but the surgeon only gets one chance: bronchoscopy marking may help the surgeon to perform sublobar resection. J Thorac Dis 2018;10:E758-60.

9. Baste JM, Soldea V, Lachkar S, et al. Development of a precision multimodal surgical navigation system for lung robotic segmentectomy. J Thorac Dis 2018;10:S1195-204.

10. Suzuki K, Saji H, Aokage K, et al. Comparison of pulmonary segmentectomy and lobectomy: Safety results of a randomized trial. J Thorac Cardiovasc Surg 2019;158:895-907.

11. Thomas PA, Berbis J, Falcoz PE, et al. National perioperative outcomes of pulmonary lobectomy for cancer: the influence of nutritional status. Eur J Cardiothorac Surg 2014;45:652-9; discussion 659.

12. Pagès PB, Delpy JP, Orsini B, et al. Epithor project (French Society of Thoracic and Cardiovascular Surgery). Propensity Score Analysis Comparing Videothoracoscopic Lobectomy With Thoracotomy: A French Nationwide Study. Ann Thorac Surg 2016;101:1370-8.

13. Travis WD, Brambilla E, Müller-Hermelink HK, et al. Pathology and Genetics: Tumours of the Lung, Pleura, Thymus and Heart. Lyon: IARC Press, 2004. 
14. Clavien PA, Barkun J, de Oliveira ML, et al. The ClavienDindo classification of surgical complications: five-year experience. Ann Surg 2009;250:187-96.

15. Zhu Y, Savage JS, Ghosh D. A Kernel-Based Metric for Balance Assessment. J Causal Inference 2018; 6:20160029.

16. Hazlett C. Kernel balancing: A flexible label-parametric weighting procedure for estimating causal effects. 2015 . arXiv: 1605.00155 .

17. Austin PC. The relative ability of different propensity score methods to balance measured covariates between treated and untreated subjects in observational studies. Med Decis Making 2009;29:661-77.

18. Stuart EA. Matching methods for causal inference: A review and a look forward. Stat Sci 2010;25:1-21.

19. Jensik RJ, Faber LP, Milloy FJ, et al. Segmental resection for lung cancer. A fifteen-year experience. J Thorac Cardiovasc Surg 1973;66:563-72.

20. Fan J, Wang L, Jiang GN, et al. Sublobectomy versus lobectomy for stage I non-small-cell lung cancer, a meta-analysis of published studies. Ann Surg Oncol 2012;19:661-8.

21. Bao F, Ye P, Yang Y, et al. Segmentectomy or lobectomy for early stage lung cancer: a meta-analysis. Eur J Cardiothorac Surg 2014;46:1-7.

22. Zhang Y, Sun Y, Wang R, et al. Meta-analysis of lobectomy, segmentectomy, and wedge resection for stage I non-small cell lung cancer. J Surg Oncol 2015;111:334-40.

23. Cao C, Chandrakumar D, Gupta S, et al. Could less be more?-A systematic review and meta-analysis of sublobar resections versus lobectomy for non-small cell lung cancer according to patient selection. Lung Cancer 2015;89:121-32.

24. Zhang L, Li M, Yin R, et al. Comparison of the oncologic outcomes of anatomic segmentectomy and lobectomy for early-stage non-small cell lung cancer. Ann Thorac Surg 2015;99:728-37.

25. Liu Y, Huang C, Liu H, et al. Sublobectomy versus lobectomy for stage IA (T1a) non-small-cell lung cancer: a meta-analysis study. World J Surg Oncol 2014;12:138.

26. Handa Y, Tsutani Y, Mimae T, et al. Complex

Cite this article as: Berg E, Madelaine L, Baste JM, Dahan M, Thomas P, Falcoz PE, Martinod E, Bernard A, Pagès PB. Interest of anatomical segmentectomy over lobectomy for lung cancer: a nationwide study. J Thorac Dis 2021;13(6):3587-3596. doi: 10.21037/jtd-20-2203 segmentectomy in the treatment of stage IA non-small-cell lung cancer. Eur J Cardiothorac Surg 2020;57:122-3.

27. Hwang Y, Kang CH, Kim HS, et al. Comparison of thoracoscopic segmentectomy and thoracoscopic lobectomy on the patients with non-small cell lung cancer: a propensity score matching study. Eur J Cardiothorac Surg 2015;48:273-8.

28. Deng B, Cassivi SD, de Andrade M, et al. Clinical outcomes and changes in lung function after segmentectomy versus lobectomy for lung cancer cases. J Thorac Cardiovasc Surg 2014;148:1186-92.e3.

29. Seder CW, Magee MJ, Broderick SR, et al. The Society of Thoracic Surgeons General Thoracic Surgery Database 2019 Update on Outcomes and Quality. Ann Thorac Surg 2019;107:1302-6.

30. Brunelli A, Salati M, Rocco G, et al. European risk models for morbidity (EuroLung1) and mortality (EuroLung2) to predict outcome following anatomic lung resections: an analysis from the European Society of Thoracic Surgeons database. Eur J Cardiothorac Surg 2017;51:490-7.

31. Pagès PB, Cottenet J, Mariet AS, et al. In-hospital mortality following lung cancer resection: nationwide administrative database. Eur Respir J 2016;47:1809-17.

32. Ohtsuka T, Kamiyama I, Asakura K, et al. Thirtyday outcomes after lobectomy or segmentectomy for lung cancer surgery. Asian Cardiovasc Thorac Ann 2015;23:828-31.

33. Zhang Z, Feng H, Zhao H, et al. Sublobar resection is associated with better perioperative outcomes in elderly patients with clinical stage I non-small cell lung cancer: a multicenter retrospective cohort study. J Thorac Dis 2019;11:1838-48.

34. Rivera C, Bernard A, Falcoz PE, et al. Characterization and prediction of prolonged air leak after pulmonary resection: a nationwide study setting up the index of prolonged air leak. Ann Thorac Surg 2011;92:1062-8; discussion 1068.

35. Charloux A, Quoix E. Lung segmentectomy: does it offer a real functional benefit over lobectomy? Eur Respir Rev 2017;26:170079. 


\section{Appendix 1}

Halim ABOU HANNA (Dijon), Salam ABOU TAAM (Quincy),Didier ADODO (Creteil), Apostolos AGRAFIOTIS (Paris), Sonia AGUIR (Clamart), Rias AKKAD (Lille), Charles AL ZREIBI (Paris), Michel ALAUZEN (Montpellier), Marco ALIFANO (Paris), Géraldine ALLAIN (Poitiers), Francesca ALLIDI (Aix-en-Provence), Nidal ALSIT (Nancy), Dan ANGELESCU (Grenoble), Valentine ANNE (Metz), Alex ARAME(Paris), Jean Philippe ARIGON (Nantes), Jalal ASSOUAD (Paris), Axel AUBERT (SaintMartin d'Hères), Jean Philippe AVARO (Toulon), Alla AVRAMENKO (Clamart), Olivier AZE (Aix-en-Provence), Alain BADIA (Paris), Patrick BAGAN (Argenteuil), Jeremy BARDET (Paris), Julie BARISIEN (Orléans), Jean Marc BASTE (Rouen), Benoit BEDAT (Marseille), François BELLENOT (Pontoise), Jocelyn BELLIER (Arras), Lotfi BENHAMED (Valenciennes), Fabien BERANGER (Toulon), Patrice BERGERON (Marseille), Jean BERJAUD (Toulouse), Pascal BERNA (Amiens), Alain BERNARD (Dijon), Jean Philippe BERTHET (Nice), Pierre BERTHOUMIEU (Toulouse), François BERTIN (Limoges), Christophe BERTON (Saran), Vincent BLIN (Vannes), Antonio BOBBIO (Paris), Guillaume BODDAERT (Clamart), Philippe BOITET (Havre), Pierre Mathieu BONNET (Marseille), Pierre BONNETTE (Suresnes), Laurent BORDIGONI (Toulon), Benjamin BOTTET(Rouen), Ilies BOUABDALLAH (Marseille), David BOULATE (Plessis Robinson), Samuel BOUTTIER (Ermont), Eric BRECHET (Limoges ), Emmanuel BRIAN (Paris), Pierre Yves BRICHON (Grenoble), Geoffrey BRIOUDE (Marseille), Laurent BROUCHET (Toulouse), Dana BUDESCU RADU (Bobigny), Evelyne CANNY HAMELIN (Paris), Brice CAPUT (Nancy), Gilles CARDOT (Boulogne), Arnaud CASANOVA (Ajaccio), Francesco CASSIANO (Suresnes), Yves CASTIER (Paris), Mathilde CAZAUX (Toulouse), Jean Baptiste CHADEYRAS (Clermont-Ferrand), Philippe CHAFFANJON (Grenoble), Alain CHAPELIER (Suresnes), Florent CHAROT (Saint-Jean), Olivier CHATAIGNER (Reims), Joséphine CHENESSEAU (Marseille), Benjamin CHEVALIER (Pessac), Thibaut CHOLLIER (Grenoble), Jean-Noël CHOPLAIN (Brest), Antoine CLARET (Lille), Armand CLUZEL (Marseille), Mathieu COBLENCE (Quincy), Charlotte COHEN (Nice), Pierre CORBI (Poitiers), Catalin COSMA (Nîmes), Mathias COURALET (Poitiers), Valinkini DA COSTA (Clermont-Ferrand), Maher DABBOUSSI (Bourges), Marcel DAHAN (Toulouse), Bassel DAKHIL (Argenteuil), Philippe DALOUS (Muret), Thomas D'ANNOVILLE (Montpellier), Florence DE DOMINICIS (Amiens ), Xavier DE KERANGAL (Le Havre), Eric DE LA ROCHE DE BRANSAT (Caluire), Alberic de LAMBERT (Chambéry), Henri de LESQUEN (Marseille), Julien DE WOLF (Suresnes), Denis DEBROSSE (Paris), Antoine DEFONTAINE (Quimper), Fréderic DELCAMBRE (Pessac), Gonzague DELEPINE (Reims), Michel DENEUVILLE (Pointe-àPitre), Gregory DESSERTENNE (Le Mans), Marie-Dominique DESTABLE (Bobigny), Xavier-Benoit D'JOURNO (Marseille), Christophe DODDOLI (Marseille), Gabrielle DREVET (Bron), Christian DROMER (Bordeaux), Jean DUBREZ (Bayonne), Caroline DUCOS (Epagny), Xavier DUCROCQ (Colmar), Antoine DUJON (Bois-Guillaume), Pascal DUMONT (Tours), Pierre DUPONT (Tours), Marion DURAND (Antony), Thierry DUROY DE CHAUMARAY (Marseille), Luciano ERALDI (Beuvry), Harry ETIENNE (Paris), Dominique FABRE (Plessis Robinson), Elie FADEL (Plessis Robinson), Pierre-Emmanuel FALCOZ (Strasbourg), Ahed FALLOUH (Pontoise), Jean-Louis FASQUEL (Quimper), Boris FEITO (Pontoise), Philippe FERNOUX (Chalon-sur-Saône), Marc FILAIRE (Clermont-Ferrand), Alex FOURDRAIN (Amiens), Ludovic FOURNEL (Paris), Sébastien FRANCO (Rochelle), Éric FRASSINETTI (Chambéry), Gil FREY (St-Etienne), Simone FURIA (Périgueux), Géraud GALVAING (Clermont-Ferrand - Jean Perrin), Emmanuel GARDET (Rochelle), Mihaela GIOL (Paris), Antoine GIRAULT (Paris), Mathieu GLORION (Suresnes), Dominique GOSSOT (Paris), Flora GOUAILLIER VULCAIN (Vannes), Bertrand GRAND (Clamart), Madalina GRIGOROIU (Paris), Renaud GRIMA (Bron), Gilles GROSDIDIER (Nancy), Sébastien GUIGARD (Saint-Martin d'Hères), Sophie GUINARD (Strasbourg), Patrice GUIRAUDET (Bobigny), Lucile GUST (Marseille), Olivier HAGRY (Chalonsur-Saône), Alexandru HAJEK (St-Etienne), Jamil HAJJ CHAHINE (Poitiers) Sarah HAMDI (Plessis Robinson), Maxime HEYNDRICKX (Caen), Kheira HIRECHE (Montpellier), Chloé HUBERT (Réunion), Romain HUSTACHE CASTAING (Pessac), Jules IQUILLE (Paris), Sophie JAILLARD THERY (Lille), Aurelie JANET VENDROUX (Paris), Christophe JAYLE (Poitiers), Jacques JOUGON (Pessac), David KACZMAREK (St-Etienne), Alexandre KARSENTI (Paris), Joseph KHALIFE (Villeneuve St-Georges), Thérèse Carla KHALIFE HOCQUEMILLER (Paris), Christophe KLEIN (Bordeaux), Philippe KLEINMANN (St-Cloud), Erik KOVACS (Bron), Philippe LACOSTE (Nantes), Benoit LAHON (Bayonne), Christophe LANCELIN (Brest), Hubert LATHELIZE (Rochelle), Françoise LE PIMPEC BARTHES (Paris), Jean Philippe LE ROCHAIS (Caen), Marielle LE ROUX(Paris), Didier LEFANT (Rochelle), Antoine LEGRAS (Tours), Bernard LENOT (Saint-Brieuc), Francesco LEO (Périgueux), Jean-François LEVI (Ermont), Francis LEVY (Bordeaux ), Pierre LHOMMET (Colmar), Fréderic LOREILLE (Tours), Joseph LUCCIARDI (Bastia), John Tarun MAC BRIDE WINDSOR (Clamart), Pierre MAGDELEINAT 
(Argenteuil), Arez MAMELI (Meaux), Giuseppe MANGIAMELI (Paris), Éric MARCADE (Nice), Emmanuel MARTINOD (Bobigny), Charles MARTY ANE (Montpellier), Hicham MASMOUDI (Paris), Gilbert MASSARD (Strasbourg), Jean-Michel MAURY (Bron), Diana MAYEUR (Pau), Florence MAZERES MARTI (Bayonne), Antonio MAZZELLA (Paris), Lucia MAZZONI (Paris), Jean MELKI (Rouen), Éric MENSIER (Lille), Olaf MERCIER (Plessis Robinson), Thierry MERLINI (Nice), Geoni MERLUSCA (Amiens), David METOIS (Saran), Jean Pierre MEUNIER (Avignon), Antonio MINNITI (Pau), Delphine MITILIAN (Plessis Robinson), Cécile MOISAN (Saint-Brieuc), Germain MONGA PELAMI (Colmar), François MONTAGNE (Rouen), Pierre MORDANT (Paris), Jean Michel MOREAU (Nantes), Jérôme MOUROUX (Nice), Antoine MUGNIOT (Nantes), Sacha MUSSOT (Plessis Robinson), Adel NAAMEE (Clermont-Ferrand), Nidal NAFFAA (Avignon), Claudia NATALE (Toulon), Anapa NAUTA (Tours), Éric N'DIHOKUBWAYO (Avignon), Jessica NESCI (Bobigny), Pierre NEVEU (Talant), Charles NEVEU (Saint-Jean), Davy NGABOU (Bobigny), Van Manh NGUYEN (Nevers), Anne OLLAND (Strasbourg), Florin ONEA (Amiens), Ilaria ONORATI (Bobigny), Bastien ORSINI (Marseille), Alessandro ORSINI (Metz), Pierre-Benoit PAGES (Dijon), Olivier PAGES (Cornebarrieu), Alessandra PAOLINI (Bobigny), Éric PARIETTI (St-Etienne), Edouard PARIS (Nantes), Arnaud PATOIR (St-Etienne), Antoine PAUMIER (Quimper), Gérard PAVY (Arras), Christophe PEILLON (Rouen), Matthieu PERET (Perpignan), Marine PERETTI (Bobigny), Christian PERIGAUD (Nantes), Sébastien PEROU (Grenoble), Cédric PERROTIN (Nice), Boriana PETKOVA MARTEAU (Toulon), Karel PFEUTY (Saint-Brieuc), Arnaud PFORR (Avignon), Thibault PIERARD (Pontoise), Paul André PIETRI (Marseille), Augustin PIRVU (Grenoble), Axel PLAISANT (Lille), Daniel POP (Nice), Henri PORTE (Lille), Calin PRECUP (Bobigny), Ciprian PRICOPI (Paris), Mathilde PRIETO (Nancy), Bastien PROVOST (Brest), Maksim PRYSHCHEPAU (Metz), Pierre RABINEL (Toulouse), Turaia RAMI (Bobigny), Jérémie REEB (Strasbourg), Jean François REGNARD (Paris), Stéphane RENAUD (Nancy), Claire RENAUD (Toulouse), Bertrand RICHARD DE LATOUR (Rennes), Pierre RIERA (Aix-en-Provence), Alain RIND (Réunion), Philippe RINIERI (Rouen), Elodie RIVE (Toulon), Caroline RIVERA (Bayonne), Joël RIVIERE (Cherbourg), Arnaud RODRIGUEZ (Pessac), Gaétane ROQUET (Caluire), Jean Christian ROUSSEL (Nantes), Arnaud ROUSSEL (Paris), Jean François ROUX (Echirolles), Simon ROUZE (Rennes), Philippe RUDONDY (Marseille - St-Joseph), Michel SAAB (Bois-Guillaume), Babak SADEGHI LOOYEH (Ploemeur), Edouard SAGE (Suresnes), Nicolas SALLEY (Brest), Sébastian SANDU (Reims), Nicola SANTELMO (Strasbourg), Ana Maria SANTOS PORTELA (Bobigny), Matthieu SARSAM (Rouen), Agathe SEGUIN GIVELET (Paris), Joseph SEITLINGER (Nancy), Thomas SENAGE (Nantes), Benoit SEVRAY (Vannes), Joëlle SIAT (Nancy), Gaétan SINGIER (Lyon), Valentin SOLDEA (Bron), Laurence SOLOVEI (Toulouse), Abdulrazzaq SULAIMAN (Saint-Etienne), Ecaterina SURMEI PINTILIE (Lille), Mayeul TABUTIN (Lyon), Marie TARDY (Clermont-Ferrand), Pierre TESSON (Le Mans), Pascal-Alexandre THOMAS (Marseille), Matthieu THUMEREL (Pessac), Olivier TIFFET (Saint-Etienne), Bruno TREMBLAY (Meaux), Jeremy TRICARD (Limoges), Delphine TROUSSE (Marseille), Jean-Pierre VALVERDE (Réunion), Cristina Emanuela VASILE (Brest), Nicolas VENISSAC (Nice), Jean Philippe VERHOYE (Rennes), Alain VEYRET (Agen), Renaud VIDAL (Marseille), Claire VISTE (Amiens), Claudia VLAS TAUTU (Orléans), Alejandro WITTE PFISTER (Amiens), Didier WOELFFLE (Valenciennes), Rym ZAIMI (Argenteuil). 